\title{
Organizational justice perception and job satisfaction of medical personnel working in primary health care services (An application within Sivas public health management)
}

\section{Birinci basamak sağlık hizmetlerinde çalışan sağlık personelinin örgütsel adalet algısı ve iş doyumu (Sivas Halk Sağlığı Müdürlüğünde Bir Uygulama)}

İzzet Karataş ${ }^{1}$, Ůmit Naldö ken²

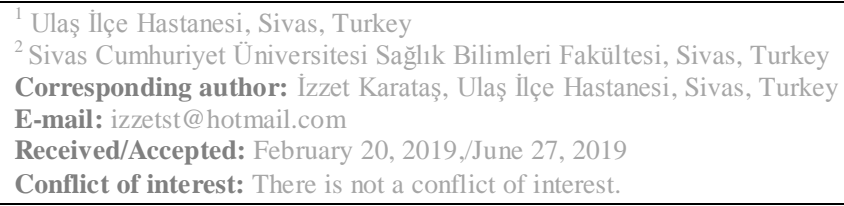

\section{SUMMARY}

Organizational justice is one of the important factors that affect the job satisfaction and motivation of employees based on Adams' "equity theory." It is possible to propound that the performance of personnel increase within the organizations where distributive, interactional, and procedural justice function properly. This study aims at examining the effect of medical personnel working in primary health care services on organizational justice perception and job satisfaction.

In the study, a t-test was used as a statistical analysis to check if the two independent samples had different averages from a given variable. Anova test was used to determine the difference in averages of two or more groups. Separate frequency tests were conducted for each question used in the survey in order to determine the consistency of answers. Correlation analysis was applied to determine whether there is a linear relationship between two numerical measurements and if so, the direction and intensity of this relationship.

In the study, two different scales were used as a data collection tool. These are "Minnesota Satisfaction Questionnaire" and "Organisational Justice Questionnaire." Besides, some questions were asked in an attempt to analyze socio-demographic variants of participants. As a result of the study, it is seen that there is a significant relationship between job and gender and education and job satisfaction scale average.

Keywords: Organisational justice, medical personnel
İzzet Karataş

iD Ümit Naldöken

ORCID IDs of the authors: I.K. 0000-0001-7714-0413 Ü.N. 0000-0003-1295-8358

ÖZET

Örgütsel adalet, Adams'ın "eşitlik teorisine" dayanan ve çalışanların iş tatmini, motivasyonuna etki eden önemli unsurların başında gelmektedir. Dağıtım, etkileşim, süreç adaletinin sağlıklı yaşandığı kurumlarda çalıșan performansının üst düzeylere çıktığını söylemek mümkündür. Bu çalışma birinci basamak sağlık hizmetlerinde çalışan personelin örgütsel adalet algısı ve iş doyumuna olan etkisi incelenmeyi amaçlamıştır. 
ortalamalarının farkını tespit etmek amacıyla Anova testi kullanılmıștır. Ankette kullanılan sorulara verilen cevapların yoğunluğunu görmek için her soruya ayrı frekans testi uygulanmıştır. İki sayısal ölçüm arasında doğrusal bir ilişki olup olmadığını, eğer böyle bir ilişki varsa bu ilişkinin yönünü ve şiddetinin ne olduğunu belirlemek için korelasyon analizi uygulanmiştır.

Çalışmada veri toplama aracı olarak iki farklı ölçek kullanılmıştır. Bunlar, "Minnesota iş doyum ölçeği” ve "Örgütsel Adalet Ölçeği” dir. Bunun yanı sıra katılımcıların sosyo demografik değișkenlerini incelemek amacıyla da bazı sorularda sorulmuştur. Çalışma sonucunda, görev ve cinsiyet arasında, Eğitim ve iş doyum ölçeği ortalaması arasında, anlamlı bir iliş̧ki görülmüştür.

Anahtar sözcükler: Örgütsel adalet, tıbbi personel

\section{INTRODUCTION}

As it is known, regardless of the subject of activity of the organization is, one of the main objectives is to embody personnel who are satisfied with their job and harmonious with their environment. It is also known that thanks to the satisfied and harmonious personnel, performance will reach high levels. Thus, job satisfaction has uttermost importance from the point of both employer and personnel.

In today's world, people as a source of information for organizations constitute a very important source of funds. The harsh market conditions and the superiority of organizations in competing with one another are only possible with the commitment of the personnel to the organization. The most important factor directly affecting the commitment of individuals of the organization is their trust in organization and job satisfaction perception. Organizational justice includes equitable and moral applications that exist within an organization and being encouraged towards these attitudes. As it is clear from the term, it ensures that justice commands within the organization. Apart from some duties on the personnel for continuity of organizational success, ensuring the authority and equity within the organization, and the effect of justice to the performance of personnel has been the subject of many studies. (Taşkıran, 2011, Saklan, 2010, Özdevecioğlu, 2003)

\section{THE STUDY}

\section{Problem Situation}

The existence of inequitable attitudes in almost all classes of community wreaks havoc on the individuals getting affected by this situation. Incompatibility between the building blocks of an organization in case organizational justice could not be accomplished turns into unhappiness and results in a decrease in personnel productivity and even release from the organization. In addition, when organizational justice functions, the performance of personnel increases, and job satisfaction is provided rather than these undesirable actions. From this point of view, the problem statement of the study has been defined as; "How are the organizational justice perception and job satisfaction of the personnel within the medical institutions named as primary health care services?"

\section{The Objective of the Study}

The lack of studies on the personnel working in the primary health care services has railroaded us into conducting this study. Accordingly, the main objective of this study is to fill the deficiency in the literature and to be precedent for future studies.

\section{Model and Hypothesis of the Study}

The scanning model was used in order to determine the existing situation in this study analyzing organizational justice perception and job satisfaction of the personnel working in the primary health care services. The sample group should be chosen broadly in this model. The questionnaire technique is the easiest and the best quantitative data collection method in order to reach this sample group. Based on the survey data obtained, generalization is attempted. Thus, the hypotheses being used in the study are introduced below.

\section{Type of the Study}

Type of the study is a cross-sectional study from analytical studies. In this type of study, generalizable results for the whole society are examined.

\section{Population and Samples of the Study}

Midwives, Nurses, Health Officers, EMTs, Doctors, Health Technicians, Administrative Personnel, and Medical Secretaries working in primary health care services will be included in the study. According to the data obtained from Sivas Public Health Management, 147 personnel in İbn-i Sina Community Health Care Centre incorporating under the Management, 22 personnel in Public Health Laboratory, 62 personnel within the Management and 584 active personnel in district Community Health Care Centres are identified as 
the target population of the study. Of 815 personnel in total, 262 employees are taken into the sample. The sample was calculated with the formula $n=N \cdot t^{2}$.p.q $/ \mathrm{d}^{2}$. $(\mathrm{N}-1)+\mathrm{t}^{2}$.p.q and sampling were found 262, which is a formula being used in order to determine the number of individuals in the sample according to the frequency of occurrence in case the number of individuals in the population is known.

\section{DATA COLLECTION TOOLS}

The collection of data needed to complete the study titled "Organisational Justice Perception And Job Satisfaction Of Medical Personnel Working In Primary Health Care Services" requires a system and a technique. The survey technique was used as a data collection technique and tool in our study.

The first section of the survey having 3 sections in total has 8 questions in an attempt to determine socio-demographic features such as gender, age, educational background, marital status, duty within the institution, working hours within the institution, monthly income of the participants. These questions were chosen by the researcher. In the second section of the study, it is aimed to determine participants' belief in organizational justice using "organizational justice questionnaire."

Organizational Justice Questionnaire: This questionnaire was developed by Niehoff and Moorman (1993) with the intent of measuring organizational justice. The first 9 questions of this questionnaire, which consists of 20 in total, measures interactional justice, 10 and 15 measures procedural justice, 16 and 20 are for distributive justice. (Yükssekbilgili vd., 2015:47)

Minnesota Satisfaction Questionnaire: MSQ, which was first developed by Dawis, Weiss, England, and Lofquist, was adapted to Turkish by conducting reliability analysis by Baycan in 1985 by conducting reliability analysis. The questionnaire consisting of 20 questions (with a 1 to 5 scale scoring) has been prepared with very satisfied, satisfied, undecided, unsatisfied, very unsatisfied options in the form of a Likert scale questionnaire and participants were asked to mark one of them which seems suitable.

\section{Evaluation of Data}

As a result of our study the data, when the parametric test assumptions used in evaluating the data to be entered by being encoded into the SPSS (ver: 22.0) package program are fulfilled; (Kolmogorov-Smirnov) significance test of difference between two means, Analysis of Variance, Tukey's test; when the parametric test assumptions are not fulfilled; Mann-Whitney U test, to determine the relation and connection Regression and Correlation Analysis, KruskalWallis test; and as evaluating the data obtained by enumeration, Chi-Square test will be used; and margin of error will be taken as 0.05 .

\section{Ethical Aspect of the Study}

Written permission will be demanded from Sivas Public Health Management before starting the study. Volunteers working for Sivas Public Health Institution between 01/05/2017 - 01/08/2017 and who accepted participating in the survey were given pre-prepared questionnaires with face-toface methods and questionnaires were collected afterward. It is expected to take 10 minutes on average to fill the questionnaire. It was clarified that participants would not write their names down, the data obtained with the study will remain under the seal of secrecy, and will only be used for scientific purposes. Following the collection of all questionnaires, the survey stage will be ended. A sample of the questionnaire used in the study is given in the annex.

\section{Reliability Analyses}

The questionnaires were subjected to separate reliability analyses in order to determine whether our sample group's answers to the questions in the questionnaire are valid and reliable. Accordingly, Cronbach's Alpha values of all perception questionnaires partaking in the Organisational Justice Questionnaire were found above 0.70, which is an acceptable threshold. All in all, Cronbach's Alpha value of the Organisational Justice Questionnaire was found at 0.95 , such a high level namely reliable to the highest degree. It is exhibited in detail in the table below. 
Table 1: Cronbach's Alpha Values of Organisational Justice Questionnaire

\begin{tabular}{lc}
\hline Organisational Justice Questionnaire & $\begin{array}{c}\text { Cronbach's } \\
\text { Alpha }\end{array}$ \\
\hline Interactional Justice & 0.87 \\
Procedural Justice & 0.90 \\
Distributive Justice & 0.93 \\
HRM applications (General) & 0.95 \\
\hline
\end{tabular}

As a result of reliability analysis, Cronbach's Alpha values of sub-dimensions of organizational justice questionnaire: are calculated 0.90 for procedural justice, 0.93 for distributive justice, and 0.87 for interactional justice. Examining the obtained Cronbach's alpha values, the reliability degree of the questionnaire was accepted to be high.

Yet another questionnaire used in our study is the Minnesota job satisfaction questionnaire. This questionnaire consists of two sub-dimensions: internal and external. Internal aspect of it creates sub-components such as Safety, Moral Values, Utilisation of Skills, Social Service, Success, Independence, Performed Activities, Authority,
Diversity, Creativity, Responsibility; while External aspect creates subheadings such as relationship with colleagues, administrative relationships, administrative decision making skill, university policies and applications, being appreciated, advancement, evolvement, working conditions, salary.

Cronbach's Alpha values were used in order to determine whether the answers in the questionnaire are valid and reliable. The validity and reliability of the questionnaire were confirmed by obtaining the acceptable value, which is 0.70 . It is exhibited in detail in the table below.

Table 2: Cronbach's Alpha Values of Minnesota Job Satisfaction Questionnaire

\begin{tabular}{lc}
\hline Organizational Justice Aspects & Cronbach's Alpha \\
\hline Internal Satisfaction & 0.90 \\
External Satisfaction & 0.85 \\
Minnesota Job Satisfaction Q. & 0.93 \\
(General) & \\
\hline
\end{tabular}

As seen in the table, the reliability results of the questionnaire and its sub-dimensions were examined. Accordingly, the degree of reliability of sub-questionnaire internal satisfaction was found to be 0.90 , which is quite above the acceptable degree that is 0.70 . Similarly, subdimension of external satisfaction has a reliability degree such as 0.85 Overall reliability of this questionnaire was found to be 0.93 . It is possible to say that the given answers are statistically reliable to the highest level.

The majority of participants are male and in the 25-35 age group. A great majority of the sample group is single; the education level of those is college. The period of office for the majority is up to 5 years. The monthly income of our sample group is between 3001 and 4000 TRY, and the difficulty level of their jobs is moderate. 
Table 3: Socio-Demographic Characteristics of Workers

\begin{tabular}{|c|c|c|c|}
\hline \multicolumn{2}{|c|}{ Parameters $(n=262)$} & $\mathbf{n}$ & $(\%)$ \\
\hline \multirow[t]{2}{*}{ Gender } & Male & 133 & 50.8 \\
\hline & Female & 129 & 49.2 \\
\hline \multirow[t]{5}{*}{ Age group (year) } & Under 25 & 58 & 22.1 \\
\hline & $26-35$ & 95 & 36.3 \\
\hline & $36-45$ & 70 & 26.7 \\
\hline & $46-55$ & 34 & 13.0 \\
\hline & $56+$ & 5 & 1.9 \\
\hline \multirow[t]{2}{*}{ Marital Status } & Married & 77 & 29.4 \\
\hline & Single & 185 & 70.6 \\
\hline \multirow[t]{5}{*}{ Education Level } & High School & 76 & 17.9 \\
\hline & College & 126 & 42.4 \\
\hline & Bachelor's Degree & 111 & 29.6 \\
\hline & Master's Degree & 26 & 9.9 \\
\hline & $\begin{array}{l}\text { Doctorate/Specialisation in } \\
\text { Medical }\end{array}$ & 5 & 1.9 \\
\hline \multirow[t]{5}{*}{ Incumbency (year) } & $0-5$ & 111 & 42.4 \\
\hline & $6-10$ & 69 & 26.3 \\
\hline & $11-15$ & 38 & 14.5 \\
\hline & $16-20$ & 14 & 5.3 \\
\hline & 21 and over & 30 & 11.5 \\
\hline \multirow[t]{4}{*}{ Monthly income } & $1001-2000$ & 21 & 8.0 \\
\hline & $2001-3000$ & 87 & 33.2 \\
\hline & $3001-4000$ & 126 & 48.1 \\
\hline & 4001 and over & 28 & 10.7 \\
\hline \multirow[t]{5}{*}{ Is your workload heavy? } & Very heavy & 10 & 3.8 \\
\hline & Heavy & 46 & 17.6 \\
\hline & Moderate & 170 & 64.9 \\
\hline & Light & 32 & 12.2 \\
\hline & Very light & 4 & 1.5 \\
\hline
\end{tabular}


Table 4: Percentage distributions of answers to organizational justice questionnaire (\%)

\begin{tabular}{|c|c|c|c|c|c|c|}
\hline & & 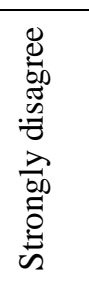 & 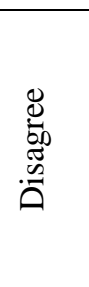 & 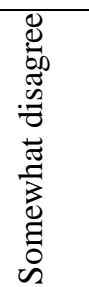 & 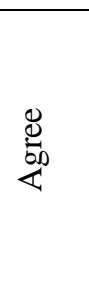 & 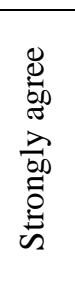 \\
\hline \multirow[t]{2}{*}{ 1. Your work schedule is fair. } & $(\%)$ & 6.1 & 16.4 & 32.4 & 35.1 & 9.9 \\
\hline & $\mathrm{n}$ & 16 & 43 & 85 & 92 & 26 \\
\hline \multirow[t]{2}{*}{ 2. I reckon that my salary is fair. } & $(\%)$ & 16.8 & 24.4 & 26.3 & 28.6 & 3.8 \\
\hline & $\mathrm{n}$ & 44 & 64 & 69 & 75 & 10 \\
\hline \multirow[t]{2}{*}{ 3. I reckon that my workload is fair. } & $(\%)$ & 9.9 & 19.5 & 27.5 & 37.4 & 5.7 \\
\hline & $\mathrm{n}$ & 26 & 51 & 72 & 98 & 15 \\
\hline \multirow{2}{*}{$\begin{array}{l}\text { 4. Considering as a whole, I reckon that the gains I made } \\
\text { from my workplace are fair. }\end{array}$} & $(\%)$ & 6.9 & 15.6 & 29.8 & 41.6 & 6.1 \\
\hline & $\mathrm{n}$ & 18 & 41 & 78 & 109 & 19 \\
\hline \multirow[t]{2}{*}{ 5. I reckon that my work responsibilities are fair. } & $(\%)$ & 6.1 & 16.8 & 29.0 & 40.8 & 7.3 \\
\hline & $\mathrm{n}$ & 16 & 44 & 76 & 107 & 22 \\
\hline \multirow{2}{*}{$\begin{array}{l}\text { 6. Business decisions are taken impartially by the } \\
\text { managers. }\end{array}$} & $(\%)$ & 9.9 & 20.6 & 29.8 & 31.3 & 8.4 \\
\hline & $\mathrm{n}$ & 26 & 54 & 78 & 82 & 15 \\
\hline \multirow{2}{*}{$\begin{array}{l}\text { 7. Managers consult all employees before taking a } \\
\text { business decision. }\end{array}$} & $(\%)$ & 16.0 & 24.8 & 30.9 & 22.5 & 5.7 \\
\hline & $\mathrm{n}$ & 42 & 65 & 81 & 59 & 16 \\
\hline \multirow{2}{*}{$\begin{array}{l}\text { 8. Managers collect correct and complete information } \\
\text { before taking a business decision. }\end{array}$} & $(\%)$ & 12.6 & 22.1 & 34.0 & 25.2 & 6.1 \\
\hline & $\mathrm{n}$ & 33 & 58 & 89 & 66 & 17 \\
\hline \multirow{2}{*}{$\begin{array}{l}\text { 9. Managers explain taken decisions to the employees } \\
\text { and give additional information if requested. }\end{array}$} & $(\%)$ & 10.3 & 18.7 & 34.4 & 30.2 & 6.5 \\
\hline & $\mathrm{n}$ & 27 & 49 & 90 & 79 & 22 \\
\hline \multirow{2}{*}{$\begin{array}{l}\text { 10. All taken business decisions are applied impartially } \\
\text { to all employees getting affected by these. }\end{array}$} & $(\%)$ & 12.6 & 20.2 & 30.5 & 28.2 & 8.4 \\
\hline & $\mathrm{n}$ & 33 & 53 & 80 & 74 & 25 \\
\hline \multirow{2}{*}{$\begin{array}{l}\text { 11. Employees can object to the taken business decisions } \\
\text { or can request these to be reconsidered by top-level } \\
\text { authorities. }\end{array}$} & $(\%)$ & 13.7 & 17.2 & 26.7 & 32.8 & 9.5 \\
\hline & $\mathrm{n}$ & 36 & 45 & 70 & 85 & 32 \\
\hline \multirow{2}{*}{$\begin{array}{l}\text { 12. When making decisions about my business, my } \\
\text { managers treat me kindly and with care. }\end{array}$} & $(\%)$ & 3.4 & 9.2 & 30.5 & 44.7 & 12.2 \\
\hline & $\mathrm{n}$ & 9 & 24 & 80 & 117 & 32 \\
\hline \multirow{2}{*}{$\begin{array}{l}\text { 13. When making decisions about my business, my } \\
\text { managers treat me respectfully and pay special attention. }\end{array}$} & $(\%)$ & 2.7 & 11.1 & 29.8 & 44.7 & 11.8 \\
\hline & $\mathrm{n}$ & 7 & 29 & 80 & 117 & 31 \\
\hline \multirow{2}{*}{$\begin{array}{l}\text { 14. When making decisions about my business, my } \\
\text { managers are sensitive to my personal needs. }\end{array}$} & $(\%)$ & 5.7 & 14.5 & 30.2 & 34.7 & 14.9 \\
\hline & $\mathrm{n}$ & 15 & 38 & 79 & 90 & 39 \\
\hline \multirow{2}{*}{$\begin{array}{l}\text { 15. When making decisions about my business, my } \\
\text { managers are honest and intimate to me. }\end{array}$} & $(\%)$ & 4.2 & 11.8 & 30.5 & 38.5 & 14.9 \\
\hline & $\mathrm{n}$ & 11 & 31 & 80 & 100 & 39 \\
\hline \multirow{2}{*}{$\begin{array}{l}\text { 16. When making decisions about my business, my } \\
\text { managers look after my rights as an employee. }\end{array}$} & $(\%)$ & 5.3 & 12.2 & 33.6 & 35.9 & 13.0 \\
\hline & $\mathrm{n}$ & 14 & 32 & 88 & 94 & 34 \\
\hline \multirow{2}{*}{$\begin{array}{l}\text { 17. My managers discuss the consequences of decisions } \\
\text { in my business with me. }\end{array}$} & $(\%)$ & 7.6 & 20.6 & 31.3 & 28.6 & 11.8 \\
\hline & $\mathrm{n}$ & 20 & 54 & 82 & 75 & 31 \\
\hline \multirow{2}{*}{$\begin{array}{l}\text { 18. My managers show proper reasons for the decisions } \\
\text { in my business. }\end{array}$} & $(\%)$ & 6.9 & 17.9 & 28.6 & 36.3 & 10.3 \\
\hline & $\mathrm{n}$ & 18 & 47 & 75 & 95 & 27 \\
\hline \multirow{2}{*}{$\begin{array}{l}\text { 19. When making decisions about my business, my } \\
\text { managers make reasonable statements to me. }\end{array}$} & $(\%)$ & 5.0 & 17.6 & 29.4 & 38.2 & 9.9 \\
\hline & $\mathrm{n}$ & 13 & 46 & 77 & 100 & 26 \\
\hline \multirow{2}{*}{$\begin{array}{l}\text { 20. My managers explain clearly all the decisions about } \\
\text { my business. }\end{array}$} & $(\%)$ & 5.3 & 20.6 & 26.3 & 35.9 & 11.8 \\
\hline & $\mathrm{n}$ & 14 & 54 & 69 & 94 & 31 \\
\hline
\end{tabular}


As seen in the table, the percentage distribution of answers to the organizational justice questionnaire is given. The number of participants who think the work schedule is fair is greater than those who do not. The number of the ones who think their salary is fair is higher than those who do not. The vast majority do not think that the workload is fair. The number of ones who reckon that the gains they made are fair is below the ones who do not think so. The large majority of participants do not think the workload is fair. Our sample group does not think the decisions taken by managers are fair.

Our sample group thinks the managers collect correct and complete information before taking a business decision. It is seen that the vast majority in our sample group disagree on the judgment of "employees can object to the taken business decisions or can request these to be reconsidered by top-level authorities." It is seen that the vast majority of participants agree to a large extent on the judgment of "when making decisions about my business, my managers treat me kindly and with care."

It is seen that the majority of our sample group agrees on the judgment of "when making decisions about my business, my managers are sensitive to my personal needs." And it is also seen that our sample group mostly agree on the judgments of "when making decisions about my business, my managers make reasonable statements to me" and "my managers explain clearly all the decisions about my business."

As is seen in the table, the percentage proportions of answers of our group to "the Minnesota job satisfaction questionnaire" were examined. Accordingly, the percentages of like-minded attitudes under the "on my present job" title are as follows.

It is seen that $53.4 \%$ are satisfied with 'being able to keep busy all the time', $49.6 \%$ are satisfied with 'the chance to work alone on the job', and the greater majority are satisfied with "the chance to do different things from time to time' and 'the chance to be "somebody" in the community" judgments. And all of the answers are 'satisfied' which can be regarded as positive for all the remaining judgements such as: the way my boss handles his/her workers, the competence of my supervisor in making decisions, being able to do thing that don't go against my conscience, the way my job provides for steady employment, the chance to do things for other people, the chance to tell people what to do, the chance to do something that makes use of my abilities.

The way company policies are put into practice, my pay and the amount of work I do, the chances for advancement on this job, the freedom to use my own judgment, the chance to try my own methods of doing the job, the working conditions, the way my co-workers get along with each other, the praise I get for doing a good job, the feeling of accomplishment I get from the job.

Examining the participants with regards to the gender according to the result of the study, since $\mathrm{p}(0.02)$ value is below $\mathrm{p}<0.05$ in the given answers of 'being able to do things that don't go against my conscience,' there is a meaningful statement. It is seen that the participants in the questionnaire act conscientiously in their job as they scruple in things that go against their conscience. 
Table 5: Percentage distributions of answers given to Minnesota job satisfaction questionnaire (\%)

\begin{tabular}{|c|c|c|c|c|c|c|}
\hline ON MY PRESENT JOB & & 胥 & 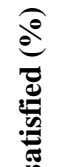 & 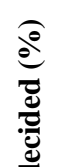 & $\underbrace{\frac{8}{6}}_{\frac{0}{2}}$ & D. \\
\hline Being able to keep bust all the time & $(\%)$ & 5.3 & 9.9 & 22.9 & 53.4 & 8.4 \\
\hline & $\mathrm{n}$ & 14 & 26 & 60 & 140 & 22 \\
\hline The chance to work alone on the job & $(\%)$ & 6.1 & 16.0 & 21.8 & 49.6 & 6.5 \\
\hline & $\mathrm{n}$ & 16 & 42 & 57 & 130 & 17 \\
\hline The chance to do different things from time to time & $(\%)$ & 5.3 & 13.0 & 21.0 & $\mathbf{5 0 . 8}$ & 9.9 \\
\hline & $\mathrm{n}$ & 14 & 34 & 55 & 133 & 26 \\
\hline The chance to be "somebody" in the community & $(\%)$ & 5.3 & 8.0 & 22.5 & 48.5 & 15.6 \\
\hline & $\mathrm{n}$ & 14 & 21 & 59 & 127 & 41 \\
\hline The way my manager handles the employees in his/her team & $(\%)$ & 6.9 & 14.1 & 26.7 & 42.0 & 10.3 \\
\hline & $\mathrm{n}$ & 18 & 37 & 70 & 110 & 27 \\
\hline The competence of my supervisor in making decisions & $(\%)$ & 5.7 & 10.7 & 29.8 & 45.0 & 8.8 \\
\hline & $\mathrm{n}$ & 15 & 28 & 78 & 117 & 23 \\
\hline Being able to do things that don't go against my conscience & $(\%)$ & 4.6 & 6.5 & 20.2 & 59.9 & 8.8 \\
\hline & $\mathrm{n}$ & 12 & 17 & 53 & 156 & 45 \\
\hline The way my job provides for steady employment & $(\%)$ & 1.5 & 5.0 & 15.6 & 60.7 & 17.2 \\
\hline & $\mathrm{n}$ & 4 & 13 & 41 & 158 & 54 \\
\hline The chance to do things for other people & $(\%)$ & 2.3 & 5.7 & 12.6 & 58.8 & 20.6 \\
\hline & $\mathrm{n}$ & 6 & 15 & 33 & 153 & 27 \\
\hline The chance to tell people what to do & $(\%)$ & 3.8 & 11.1 & 20.6 & 54.2 & 10.3 \\
\hline & $\mathrm{n}$ & 10 & 29 & 54 & 141 & 27 \\
\hline The chance to do something that makes use of my abilities & $(\%)$ & 5.3 & 7.6 & 13.7 & 57.6 & 15.6 \\
\hline & $\mathrm{n}$ & 12 & 20 & 36 & 150 & 41 \\
\hline The way company policies are put into practice & $(\%)$ & 4.6 & 9.5 & 25.2 & $\mathbf{5 0 . 0}$ & 10.7 \\
\hline & $\mathrm{n}$ & 31 & 25 & 66 & 130 & 28 \\
\hline My pay and the amount of work I do & $(\%)$ & 11.8 & 19.5 & 17.9 & 42.0 & 8.8 \\
\hline & $\mathrm{n}$ & 31 & 51 & 47 & 110 & 23 \\
\hline The chances for advancement on this job & $(\%)$ & 15.3 & 20.6 & 25.2 & 36.6 & 2.3 \\
\hline & $\mathrm{n}$ & 40 & 54 & 64 & 96 & 6 \\
\hline The freedom to use my own judgment & $(\%)$ & 7.3 & 17.6 & 24.4 & 43.5 & 7.3 \\
\hline & $\mathrm{n}$ & 19 & 46 & 53 & 113 & 19 \\
\hline The chance to try my own methods of doing the job & $(\%)$ & 6.1 & 13.4 & 20.2 & 50.8 & 9.5 \\
\hline & $\mathrm{n}$ & 16 & 35 & 53 & 144 & 25 \\
\hline The working conditions & $(\%)$ & 6.1 & 10.7 & 16.0 & 55.3 & 11.8 \\
\hline & $\mathrm{n}$ & 16 & 28 & 42 & 144 & 31 \\
\hline The way my co-workers get along with each other & $(\%)$ & 5.3 & 5.3 & 14.5 & 55.7 & 19.1 \\
\hline & $\mathrm{n}$ & 14 & 14 & 38 & 145 & 50 \\
\hline The praise I get for doing a good job & $(\%)$ & 6.5 & 13.4 & 24.8 & 45.4 & 9.9 \\
\hline & $\mathrm{n}$ & 17 & 35 & 65 & 119 & 26 \\
\hline The feeling of accomplishment I get from the job & $(\%)$ & 4.2 & 8.0 & 17.9 & 52.7 & 17.2 \\
\hline & $\mathrm{n}$ & 11 & 21 & 47 & 138 & 45 \\
\hline
\end{tabular}


Table 6: Gender and 'being able to do things that don't go against my conscience' relationship

\begin{tabular}{|c|c|c|c|c|c|c|}
\hline & Gender & $\mathrm{N}$ & $X$ & Ss & $\mathrm{F}$ & $\mathrm{p}$ \\
\hline \multirow{2}{*}{$\begin{array}{l}\text { Being able to do things } \\
\text { that don't go against } \\
\text { my conscience }\end{array}$} & Female & 129 & 3.79 & 0.78 & \multirow[t]{2}{*}{14.477} & \multirow[t]{2}{*}{0.02} \\
\hline & Male & 133 & 3.45 & 0.99 & & \\
\hline
\end{tabular}

Table 7: Gender and 'my pay and the amount of work I do' relationship

\begin{tabular}{|c|c|c|c|c|c|c|}
\hline & Gender & $\mathrm{N}$ & $X$ & Ss & $\mathrm{F}$ & $\mathrm{p}$ \\
\hline \multirow{2}{*}{$\begin{array}{l}\text { My pay and the } \\
\text { amount of work I do }\end{array}$} & Female & 129 & 3.01 & 1.15 & 1.159 & 0.036 \\
\hline & Male & 133 & 3.32 & 1.21 & & \\
\hline
\end{tabular}

$\mathrm{P}<0.05$

Examining the participants with regards to the gender according to the result of the study, since $\mathrm{p}(0.036)$ value is below $\mathrm{p}<0.05$ in the given answers of 'my pay and the amount of work I do,' there is a meaningful statement. It is seen that the participants in the questionnaire consider the pay they get is the equivalent value for the work they do.

Table 8: Education level and 'my managers show proper reasons for the decisions in my business' relationship

\begin{tabular}{|c|c|c|c|c|c|c|}
\hline & Education Level & $\mathrm{N}$ & $X$ & Ss & $\mathrm{F}$ & $\mathrm{p}$ \\
\hline \multirow{5}{*}{$\begin{array}{l}\text { My managers show proper } \\
\text { reasons for the decisions in } \\
\text { my business. }\end{array}$} & $\begin{array}{l}\text { Primary } \\
\text { School }\end{array}$ & 50 & 3.36 & 1.10 & \multirow[t]{5}{*}{2.963} & \multirow[t]{5}{*}{0.020} \\
\hline & Associate Degree & 70 & 3.51 & 0.90 & & \\
\hline & Bachelor's Degree & 111 & 3.01 & 1.08 & & \\
\hline & Master's Degree & 26 & 3.80 & 1.31 & & \\
\hline & $\begin{array}{l}\text { Doctorate/Specialisation } \\
\text { in Medical }\end{array}$ & 5 & 3.25 & 1.10 & & \\
\hline
\end{tabular}

$\mathrm{P}<0 . \overline{05}$

Examining the participants with regards to the education level according to the result of the study, since $\mathrm{p}(0.020)$ value is below $\mathrm{p}<0.05$ in the given answers of "my managers show proper reasons for the decisions in my business.', there is a meaningful statement. Examining the answers of the participants in the questionnaire, it is seen that the managers show proper reasons for the decisions in employees' business.

Table 9: Education level and 'the competence of my supervisor in making decisions' relationship

\begin{tabular}{|c|c|c|c|c|c|c|}
\hline & Education Level & $\mathrm{N}$ & $\mathrm{X}$ & Ss & $\mathrm{F}$ & $\mathrm{p}$ \\
\hline \multirow{5}{*}{$\begin{array}{l}\text { The competence of my } \\
\text { supervisor in making } \\
\text { decisions }\end{array}$} & $\begin{array}{l}\text { Primary } \\
\text { School }\end{array}$ & 50 & 3.68 & 0.84 & \multirow[t]{5}{*}{3.316} & \multirow[t]{5}{*}{0.011} \\
\hline & Associate Degree & 70 & 3.54 & 0.86 & & \\
\hline & Bachelor's Degree & 111 & 3.16 & 1.04 & & \\
\hline & Master's Degree & 26 & 3.46 & 1.10 & & \\
\hline & $\begin{array}{l}\text { Doctorate/Specialisation } \\
\text { in Medical }\end{array}$ & 5 & 3.80 & 1.30 & & \\
\hline
\end{tabular}


Examining the participants with regards to the education level according to the result of the study, since $\mathrm{p}(0.011)$ value is below $\mathrm{p}<0.05$ in the given answers of 'the competence of my supervisor in making decisions,' there is a meaningful statement. Examining the answers of the participants in the questionnaire, it is seen that the competence of the managers in making decisions is appreciated by employees.

Table 10: Education level and 'the chance to do something that makes use of my abilities' relationship

\begin{tabular}{|c|c|c|c|c|c|c|}
\hline & Education Level & $\mathrm{N}$ & $X$ & Ss & $\mathrm{F}$ & $\mathrm{p}$ \\
\hline \multirow{5}{*}{$\begin{array}{l}\text { The chance to do } \\
\text { something that makes use } \\
\text { of my abilities }\end{array}$} & $\begin{array}{l}\text { Primary School/High } \\
\text { School }\end{array}$ & 50 & 3.90 & 0.91 & \multirow[t]{5}{*}{2.800} & \multirow[t]{5}{*}{0.026} \\
\hline & Associate Degree & 70 & 3.86 & 0.87 & & \\
\hline & Bachelor's Degree & 111 & 3.64 & 0.98 & & \\
\hline & Master's Degree & 26 & 3.19 & 1.39 & & \\
\hline & $\begin{array}{l}\text { Doctorate/Specialisation } \\
\text { in Medical }\end{array}$ & 5 & 3.80 & 0.84 & & \\
\hline
\end{tabular}

$\mathrm{P}<0 . \overline{05}$

Examining the participants with regards to the education level according to the result of the study, since $\mathrm{p}(0.026)$ value is below $\mathrm{p}<0.05$ in the given answers of 'the chance to do something that makes use of my abilities', there is a meaningful statement. Examining the answers of the participants in the questionnaire, it is seen that the employees have the chance to do something that makes use of their abilities.

\section{CONCLUSION}

In this section where the most important data will be evaluated as a result of our study examining the Organisational Justice Perception and Job Satisfaction of the Personnel Working in the Primary Health Care Services, it is seen that the Cronbach's Alpha value of the organizational justice questionnaire used in our survey has been found at 0.95 and that it has been found to have a high level of reliability. Yet in another questionnaire, which is Minnesota job satisfaction, Cronbach's Alpha value has been found at 0.93 , and it is observed that the answers are quite reliable in this questionnaire as well.

Examining the distribution of answers of our sample group to the organisational justice questionnaire, it is seen that they disagree somewhat on the judgments of "the work schedule is fair", "the managers consult all employees before taking a business decision", "the managers collect correct and complete information before taking a business decision", "the managers explain taken decisions to the employees and give additional information if requested", "all taken business decisions are applied impartially to all employees getting affected by these", "my managers discuss the consequences of decisions in my business with me"; as it is seen that they agree on all the remaining questions and statements in this questionnaire.

When the literature is examined, job satisfaction is generally examined along with motivation theories. The concept of job satisfaction has been tried to explain with many studies. Maslow's Hierarchy of Needs, Herzberg's Two-Factor Theory can be given as examples to these.

In a study by Clark (1997) made to analyze the relationship between job satisfaction and gender, he has found a difference as to gender; he declared that women have a high level of job satisfaction in comparison with the men. Yet in a study by Keser (2006) including 156 faculty members in the universities in Turkey, he has not been able to observe any significant difference between job satisfaction and gender. In this study, it was concluded that females' job satisfaction levels were slightly higher than males'; although there was no significant difference between them. In our study, no difference was found by gender. It is possible to see that the results are in contradiction with Clark's study as it is parallel with Keser's 2006 study.

Yelboğa's study on the employees in the finance sector in 2007 examined the effect of demographic variables on job satisfaction. In the results of the study, it was concluded that as the age of the participants progressed, job satisfaction increased, and there was no relationship between job satisfaction of the personnel according to gender. Similar results were obtained in our study. There is no relationship between job satisfaction by gender. In this respect, these two studies show parallelism.

In the study of Serinkan and Bardakçı (2007) aimed to investigate the job satisfaction levels of 
faculty members, it was determined that the most important factors affecting the job satisfaction of the faculty members were team management, wage, and promotion status. In our study, as well, it was found that wage was the most influential factor in job satisfaction. In this respect, these two studies contradict each other.

\section{REFERENCES}

1. Clark A.E. (1997). Why are Women So Happy at Work? Labour Economics, 4(4), 341-372.

2. Keser, A. (2005). The Relationship Between Job Satisfaction and Life Satisfaction: An application in the Automotive Sector. Work and Society: Journal of Economics and Law (7), 77-96.

3. Özdevecioğlu, M (2003). "Research on Determining the Effects of Perceived Organizational Justice on Interpersonal Aggressive Behaviour." Journal of F.E.A.S, Erciyes University, 21: 77-96.

4. Saklan, A. (2010). The Relationship of Job Satisfaction and Organisational Commitment in Organisations: An Application In The Faculty Of Theology In Selçuk University, Master's Thesis, Institute of Social Sciences, Selçuk University, Konya.
5. Serinkan, C. and Bardakçı, A. (2007). Study Concerning Job Satisfaction of Faculty Members Working in Pamukkale University. Selçuk University, Karaman Journal of F.E.A.S, 12(9), 152-163.

6. Taşkıran E. (2011). Interaction between Leadership and Organisational Silence, the Role of Organisational Justice, Beta Publication, İstanbul, 2011: 93-107.

7. Yelboğa A. (2007). Investigation of Relationship between Individual Demographic Variables and Job Satisfaction in the Finance Sector. Journal of Social Sciences, 4(2), 10-14

8. Yüksekbilgili Z., Çöpoğlu M., Gür O., (2015), Organisational Justice: A Study For A Metropolitan Municipality, Journal of Electronic Social Sciences, Volume: 14, Issue: 55(45-53) ISSN: 1304-0278 